\title{
Sustainable functioning of the finances of organizations in various sectors of the economy
}

\author{
Nadezhda Piontkevich*, and Ekaterina Shatkovskaya \\ Ural State University of Economics, 8th of March Str., 62, 620144 Ekaterinburg, Russia
}

\begin{abstract}
The current stage of development of the world economy is characterized by specific transformations that affect not only the state of the national economies of the countries of the world, but also the peculiarities of conducting financial and economic activities of individual organizations (enterprises) employed in various sectors of the economy. The emerging trends require the development of financial knowledge, skills, and financial management skills of an economic entity, which, in turn, confirms the need for in-depth theoretical and empirical studies of the organizational and economic aspects of the finances of organizations (enterprises) in various spheres of the economy. The purpose of the article is to develop theoretical and methodological provisions that form the basis for the formation of a financial management system for organizations in various sectors of the economy. The article uses modern methods of collecting and processing initial information, representative sample sets with the justification for the selection of financial indicators for the objects of financial management of organizations (enterprises). The leading method for the study of the problem of financial management of organizations (enterprises) has become the dynamic method. The problems in the world financial science in the field of studying the finances of organizations on a linear basis are identified and the need for an integrated approach is substantiated. The prospects of using a systematic approach to the formation of a financial management system for organizations in various sectors of the economy in science and practice have been proved. The theoretical significance of the study lies in the development of the theory of finance of organizations. The scientific theoretical provisions developed by the authors are aimed at improving the quality of financial management of organizations, depending on their belonging to the relevant sphere of the economy. The practical significance of the results of the work is reduced to determining the prospects for the practical use of the theory of financial management of organizations (enterprises) in various spheres of the economy in practice.
\end{abstract}

\footnotetext{
*Corresponding author: nspiont@gmail.com
} 


\section{Introduction}

Depending on belonging to different spheres of the economy, specific differences arise in the composition of all elements of the organization's management system (a set of subjects, objects, tools, goals).

This approach extends to the financial management of an organization, which is an independent integral area of its activities and at the same time an integral part of the management system of an economic entity along with systems of other functional areas.

The paper investigates the organizational aspects of the finances of organizations (enterprises) and commercial banks in the context of their specific subjects and objects of management, as well as the economic aspects of the finances of these economic entities in terms of management tools as methods of risk management and the ultimate goals of the functioning of their financial management system. The objective nature of the presence of specific features of the studied elements inherent in various spheres of the economy has been proved.

The hypothesis of the study was tested on organizations (enterprises) and commercial banks operating in 2013 - 2017 and has shown its viability.

The research hypothesis is based on the scientific interpretation of the research object, according to which the finances of organizations in various spheres of the economy are a system of monetary relations regarding the formation and use of sources of the organization's property in the process of production and / or sale of goods (works, services).

The authors have developed a scientific concept based on the generally accepted interpretation of the essence of finance of organizations (enterprises) as an integral functional part of the activities of any business entity, the implementation of which varies depending on the latter's belonging to a particular sphere of the economy.

The aim of the study is to develop theoretical and methodological provisions that reveal the logical structure of the financial activities of organizations in various sectors of the economy.

Research objectives:

- to systematize the world experience in the development of the theory of finance of organizations (enterprises) and financial management;

- to determine the organizational and economic nature of the elements of the financial management system of organizations (enterprises) and commercial banks and to identify the patterns of the formation of these systems in organizations of different spheres of the economy;

- to analyze the financial activities of organizations in different spheres of the economy according to their inherent objects of financial management, on the basis of which to determine the efficiency of the functioning of the financial management system of the studied organizations.

\section{Literature review}

The choice of the topic is due to the emerging trends in financial science, which reflect the narrowly focused interests of scientists studying the finances of organizations in the context of individual areas, problems, business entities, and spheres of activity. However, modern science requires a comprehensive approach to integrating existing financial knowledge in the field of financial management. The application of a systematic approach to understanding the essence of the financial management system of economic entities in various sectors of the economy in an unstable external and internal environment will not only reveal the causes and sources of the situation, assess the degree of achievement of the 
set goals, and "... will give the most objective assessment of the effectiveness of financial management" (24, p. 133), but it will also allow to outline development prospects.

The scientific community pays great attention to the financial management of economic entities in various spheres of the economy. The debatable aspects of this issue should be considered:

- firstly, the place of the financial management system in the general management system of an economic entity $(3$, p. $155 ; 10$, p. 59-62; 32, p. 101; 33, p. 7; 41, p. $34)$;

- secondly, the inclusion of individual elements in the financial management system $(4$, p. $132 ; 11$, p. $47 ; 34$, p. $63-64 ; 38$, p. 41$)$;

- thirdly, the choice of key performance indicators of the financial and economic activities of organizations $(14$, p. $64 ; 15$, p. $67-69 ; 16$, p. $229 ; 18$, p. $67-68 ; 19$, p. 1 ; 27 , p. $12 ; 36$, p. $71-72 ; 37$, p. 5-8);

- fourthly, the formulation of the objectives of the activities of business entities (17, p. 7; 31, p. 296-297; 43, p. 46).

The finances of organizations in various spheres of the economy as a system of monetary relations for the formation and use of funds function in accordance with the generally accepted elemental approach, according to which effective interaction of all components of the system is carried out.

We agree with the point of view of the Austrian Doctor of Philosophy L. von Bertalanffy, who understood the system as a "complex of interacting components" (13, p. 3-5) and believe that the set of elements of the financial management system of an individual economic entity is individual and depends on changes in the external and internal environment. At the same time, we consider it possible to classify the elements of this system according to the following aspects:

1) the organizational aspect involves the study of issues of interaction between subjects and objects as a controlling system and a controlled one, while the subjects become the basis for the functioning of the system, and objects oppose them in subject-practical and cognitive activity;

2) the economic aspect provides for the study of such elements as tools and the purpose of the influence of subjects on objects within the framework of the functioning of the system. From this point of view, the goal as a desired result is a benchmark for establishing norms, rules, standards for the functioning of the system, as well as for assessing its effectiveness. Instruments, on the other hand, represent various forms of practical activity, reflecting the properties of objective reality and aimed at reducing economic and financial risks.

Let us consider the financial management system of business entities in various spheres of the economy in terms of organizational and economic aspects (table 1).

Table 1. The financial management system of business entities in various spheres of the economy in terms of organizational and economic aspects

\begin{tabular}{|c|l|l|l|}
\hline $\begin{array}{c}N \\
n \backslash n\end{array}$ & Elements & \multicolumn{1}{|c|}{ Enterprise } & \multicolumn{1}{c|}{ Bank } \\
\hline \multicolumn{3}{|c|}{ Organizational aspect } \\
\hline 1 & Subjects & $\begin{array}{l}\text { - owners } \\
\text { - managers }\end{array}$ & $\begin{array}{l}\text { - external (special authorities authorized by the } \\
\text { state, including the Central Bank of the Russian } \\
\text { Federation, DIA) } \\
\end{array}$ \\
& & & $\begin{array}{l}\text { - internal (owners and managers) } \\
\end{array}$
\end{tabular}


Table 1. Continued

\begin{tabular}{|c|c|c|c|}
\hline 2 & Objects & $\begin{array}{l}\text { - money capital } \\
\text { - investments in fixed assets } \\
\text { - investments in working capital } \\
\text { - costs } \\
\text { - formation and distribution of } \\
\text { profits } \\
\text { - cash flows }\end{array}$ & $\begin{array}{l}\text { - equity (capital) } \\
\text { - the structure of monetary resources (capital and } \\
\text { liabilities) } \\
\text { - investments in fixed assets } \\
\text { - investments in the money portfolio } \\
\text { - investments in earning assets } \\
\text { - formation and distribution of profits } \\
\text { - cash flows }\end{array}$ \\
\hline \multicolumn{4}{|c|}{ Economic aspect } \\
\hline 3 & Instruments & $\begin{array}{l}\text { - standard accounting estimates } \\
\text { - additional performance } \\
\text { indicators determined by } \\
\text { management reporting }\end{array}$ & $\begin{array}{l}\text { - mandatory and estimated indicators established } \\
\text { by external actors } \\
\text { - additional performance indicators set by internal } \\
\text { actors }\end{array}$ \\
\hline 4 & $\begin{array}{l}\text { The } \\
\text { ultimate } \\
\text { goal }\end{array}$ & $\begin{array}{l}\text { ensuring the continuity of the } \\
\text { business of an economic entity } \\
\text { by achieving the required level } \\
\text { of liquidity (solvency), financial } \\
\text { stability, profitability and } \\
\text { business activity }\end{array}$ & $\begin{array}{l}\text { - ensuring the financial stability of the bank by } \\
\text { maintaining the required level of capital adequacy, } \\
\text { liquidity, improving the quality of assets, } \\
\text { profitability }\end{array}$ \\
\hline
\end{tabular}

Source: compiled by the author after: (23, p. 71-76; 29, p. 7; 35, p. 171-185).

The subjects of financial management of business entities in different areas of activity have the following differences:

- in organizations (enterprises) they include business owners and managers; - in addition to owners and managers, who are internal subjects of management, banks have an external level of management (regulation and supervision) represented by state bodies - the Central Bank of the Russian Federation (Bank of Russia) and the Deposit Insurance Agency (DIA).

The conflict of interests of owners and managers is studied by the scientific community $(5$, p. $103 ; 12$, p. $1 ; 35$, p. $90-91)$.

The objects of the financial management system of economic entities in different spheres of the economy differ:

- in organizations (at enterprises), they include a complete list of objects of financial management, including money capital, investments in fixed assets, investments in working capital, expenses, formation and distribution of profits, cash flows;

- in banks, the objects of financial management are the money portfolio, income assets in the form of credit and investment portfolios, fixed capital, loan portfolio, deposit portfolio, equity (capital), formation and distribution of profits, formation of incoming and outgoing cash flows.

The international scientific community pays great attention to such an object of financial management as money capital (sources of financing), in particular, they study:

- informal financing (trade loans, savings) $(2$, p. 1$)$;

- $\quad$ bank financing and the stock market (8, p. 1-2; 20, p. 223;26, p. 1; 28, p. 1;);

- venture and equity financing (7, p. 538; 21, p. 1182; 30, p. 609);

- factoring and accounts payable $(42$, p. 1$)$.

The policy of managing the working capital of the enterprise is also studied (22, p. 30; 25 , p. $1 ; 39$, p. 160).

In international banking, the study of objects of financial management is reduced mainly to the management of bank capital $(6$, p. $97 ; 9$, p. S1) and bank liquidity $(1$, p. 1$)$.

Financial management system tools for business entities have the following distinctive features:

- in organizations (enterprises), the necessary individual set of indicators for assessing the effectiveness of financial activities for objects of financial management is selected as the system tools. The authors have developed a mechanism for managing the finances of an economic entity, containing standard and additional estimated indicators (Figure 1); 


\begin{tabular}{|c|c|c|c|}
\hline \multirow{12}{*}{ 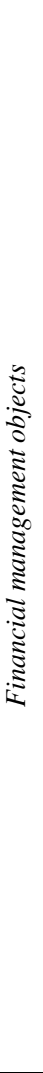 } & \multirow[t]{2}{*}{$\begin{array}{l}\text { Monetary } \\
\text { capital }\end{array}$} & $\begin{array}{l}\text { Standard } \\
\text { indicators }\end{array}$ & $\begin{array}{l}\text { Autonomy ratio, financing ratio, return on equity, capital turnover } \\
\text { ratio, etc }\end{array}$ \\
\hline & & $\begin{array}{l}\text { Additional } \\
\text { indicators }\end{array}$ & $\begin{array}{l}\text { Weighted average cost of capital, cost of organization, effect of } \\
\text { financial leverage, etc. }\end{array}$ \\
\hline & \multirow{2}{*}{$\begin{array}{l}\text { Fixed } \\
\text { capital } \\
\text { investments }\end{array}$} & $\begin{array}{l}\text { Standard } \\
\text { indicators }\end{array}$ & $\begin{array}{l}\text { Residual value of property, depreciation charges, return on fixed } \\
\text { capital, etc. }\end{array}$ \\
\hline & & $\begin{array}{l}\text { Additional } \\
\text { indicators }\end{array}$ & $\begin{array}{l}\text { Market value of property, fixed assets renewal rate, net present value, } \\
\text { internal rate of return, payback period of fixed capital investments, } \\
\text { etc. }\end{array}$ \\
\hline & \multirow[t]{2}{*}{$\begin{array}{l}\text { Investments } \\
\text { in working } \\
\text { capital }\end{array}$} & $\begin{array}{l}\text { Standard } \\
\text { indicators }\end{array}$ & $\begin{array}{l}\text { Amount of own working capital, current liquidity ratio, return on } \\
\text { working capital, profitability of production, working capital turnover } \\
\text { ratio, etc. }\end{array}$ \\
\hline & & $\begin{array}{l}\text { Additional } \\
\text { indicators }\end{array}$ & $\begin{array}{l}\text { The ratio of hard-to-sell and easy-to-sell assets, the duration of the } \\
\text { turnover of short-term assets, the minimum need for cash assets, the } \\
\text { amount of possible urgent withdrawal of cash assets, etc. }\end{array}$ \\
\hline & \multirow[t]{2}{*}{ Costs } & $\begin{array}{l}\text { Standard } \\
\text { indicators }\end{array}$ & $\begin{array}{l}\text { The volume of costs associated with production; profitability of } \\
\text { production; the volume of expenses associated with the sale of } \\
\text { products; the volume of expenses for core activities profitability of } \\
\text { core business, etc. }\end{array}$ \\
\hline & & $\begin{array}{l}\text { Additional } \\
\text { indicators }\end{array}$ & $\begin{array}{l}\text { The volume of fixed and variable costs; margin income by product; } \\
\text { share of variable cost coverage by product; critical sales volume; } \\
\text { financial safety margin; the effect of operating leverage, etc. }\end{array}$ \\
\hline & \multirow[t]{2}{*}{ Profit } & $\begin{array}{l}\text { Standard } \\
\text { indicators }\end{array}$ & $\begin{array}{l}\text { Selected types of profit, return on equity, profitability of production, } \\
\text { return on sales, return on equity, return on invested capital, etc. }\end{array}$ \\
\hline & & $\begin{array}{l}\text { Additional } \\
\text { indicators }\end{array}$ & $\begin{array}{l}\text { Critical sales volume, coverage of expenses by product (relative } \\
\text { marginal income), operating leverage effect, financial leverage effect, } \\
\text { organizational value, etc. }\end{array}$ \\
\hline & \multirow[t]{2}{*}{ Cash flows } & $\begin{array}{l}\text { Standard } \\
\text { indicators }\end{array}$ & $\begin{array}{l}\text { The amount of incoming cash flows, the amount of outgoing cash } \\
\text { flows, the resulting cash flow from operating activities, the resulting } \\
\text { cash flow from investment activities, the resulting cash flow from } \\
\text { financing activities, accumulative balance, liquidity ratios, etc. }\end{array}$ \\
\hline & & $\begin{array}{l}\text { Additional } \\
\text { indicators }\end{array}$ & Liquid cash flow, net credit position, collection ratios, etc. \\
\hline
\end{tabular}

Fig. 1. The mechanism of financial management of an economic entity $(29$, p. 9)

- in banks, financial indicators of the financial management system are reflected by the consolidated objects of financial management - by capital (own funds), quality of assets, level of liquidity and level of profitability. At the same time, three groups of indicators are established for capital, assets, liquidity:

- mandatory, established by the regulator in order to ensure the stability of the banking system as a whole and of each bank;

- estimated, established by the regulator in order to rank operating banks according to the criterion of "economic position of the bank";

- internal, established by the bank independently to achieve the ultimate goal of its financial management system (Figure 2).

\begin{tabular}{|c|c|c|c|}
\hline \multirow{4}{*}{ 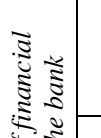 } & \multirow{3}{*}{ Capital } & \multirow{3}{*}{$\begin{array}{l}\text { Capital financial } \\
\text { indicators }\end{array}$} & Mandatory, established by the regulator \\
\hline & & & Estimated, established by the regulator \\
\hline & & & Internal, established by the bank independently \\
\hline & \multirow{3}{*}{$\begin{array}{l}\text { Asset } \\
\text { quality }\end{array}$} & \multirow{3}{*}{$\begin{array}{l}\text { Financial indicators of } \\
\text { asset quality }\end{array}$} & Mandatory, established by the regulator \\
\hline \multirow{7}{*}{ 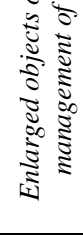 } & & & Estimated, established by the regulator \\
\hline & & & Internal, established by the bank independently \\
\hline & \multirow{3}{*}{ Liquidity } & \multirow{3}{*}{$\begin{array}{c}\text { Financial indicators by } \\
\text { liquidity level }\end{array}$} & Mandatory, established by the regulator \\
\hline & & & Estimated, established by the regulator \\
\hline & & & Internal, established by the bank independently \\
\hline & \multirow{2}{*}{ Profitability } & \multirow{2}{*}{$\begin{array}{l}\text { Financial indicators by } \\
\text { the level of profitability }\end{array}$} & Estimated, established by the regulator \\
\hline & & & Internal, established by the bank independently \\
\hline
\end{tabular}


Fig. 2. The mechanism of financial management of a commercial bank (35, p. 252-275).

The use of the considered mechanisms of financial management of economic entities in various spheres of the economy (organizations (enterprises) and commercial banks) allows achieving the set goals: it provides an opportunity to assess their financial condition, monitor the development of risk situations and allows to predict development trends and manage them.

In addition, the use of tools of the financial management system of business entities has an impact on the economy as a whole and on the trends of its development (40, p. 129).

The ultimate goal of the financial management system of business entities is reduced to the traditional economic goal of any commercial organization - making a profit. However, given the specific features of organizations in various sectors of the economy, it is necessary to clarify the ultimate goal of the financial management system:

- for organizations (enterprises) - we consider this to ensure the continuity of the latter by achieving the required level of liquidity (solvency), financial stability, profitability and business activity;

- for banks - this is to ensure their financial stability by maintaining the required level of capital adequacy, liquidity, improving the quality of assets and profitability.

The considered author's financial management system is universal, since its elements are inherent in the financial activities of all economic entities operating in the national economy. Nevertheless, as we have seen, the internal content of the elements of the system differs depending on the economic entity under consideration, which indicates the peculiarities of its current and investment activities, as well as the quality of its management.

Assessing the overall current situation in international financial science as positive, the authors note the following:

- firstly, the need to develop a systematic approach to organizing financial management of business entities and the need for coordination and deployment of all components of the financial management system of business entities;

- secondly, the need for further research of the specific features of the financial activities of economic entities in various sectors of the economy in relation to the financial management system. Further improvement of the financial activities of business entities is represented in the development of private management systems for various objects of financial management of business entities in various spheres of the economy.

\section{Materials and methods}

The test of the applicability of the author's theoretical and methodological approach to the formation of a financial management system for economic entities in different spheres of the economy was implemented in practice through the analysis of key performance indicators for financial management objects for operating organizations (enterprises) of the Russian Federation and operating Russian commercial banks from 2013 to 2017. The research is based on the data of the Russian online publication "Information resource SPARK".

The article uses a set of basic research methods, namely: scientific abstraction, logical, dialectical, comparative analysis, the method of expert assessments, economic and mathematical methods, dynamic methods. 
An analytical review of the financial indicators of the activities of organizations and banks of the Russian Federation was carried out for the objects of financial management for the period from 2013 to 2017.

\section{Results and discussion}

To analyze the effectiveness of the financial management system of economic entities in different spheres of the Russian economy, operating organizations (enterprises) and operating commercial banks were selected for the period from 2013 to 2017.

Analysis of the financial activities of organizations in the Russian Federation in 20132017 by objects of financial management is presented in Table 2 .

Based on the results of the analysis, the authors came to the following conclusions.

1. The growth rates of the volume of shipped goods of own production, works and services performed on their own in the Russian Federation for the analyzed period are $43.42 \%$, the growth rate of investments in fixed assets in the Russian Federation is $18.71 \%$, which generally reflects the general trend of moderate growth of the national economy.

2. The growth rates of accounts payable of organizations, including overdue ones, exceed the growth rates of accounts receivable of organizations for the analyzed period. This indicates the desire of organizations to increase their solvency - the current liquidity ratio has grown by $21.95 \%$ over the past five years.

3. During the study period, the profitability of organizations' assets increased by $17.78 \%$, and the profitability of goods, products, works, and services of organizations sold by $7.14 \%$. In 2017 , there is a decrease in these indicators due to the crisis in the economy.

4. The ability of organizations to support their economic activities with their own funds has sharply decreased ( 3 times) over five years, which led to an increase in borrowed resources.

Financial indicators of the activities of organizations in the Russian Federation for 2013-2017 demonstrate the state and the dynamics of the development of the Russian economy, as well as the quality of financial management at the level of organizations (enterprises).

Analysis of the financial activities of operating commercial banks in the Russian Federation in 2013-2017 for enlarged objects of financial management is presented in Table 3.

Table 2. Financial indicators of the activities of organizations in the Russian Federation in 20132017

\begin{tabular}{|c|c|c|c|c|c|c|c|c|c|c|}
\hline \multirow[b]{2}{*}{$N$} & \multirow[b]{2}{*}{ Indicator name } & \multirow{2}{*}{$\begin{array}{r}2013 \\
\frac{\pi}{3} \\
0\end{array}$} & \multicolumn{2}{|c|}{2014} & \multicolumn{2}{|c|}{2015} & \multicolumn{2}{|c|}{2016} & \multicolumn{2}{|c|}{2017} \\
\hline & & & $\frac{\tilde{5}}{2}$ & 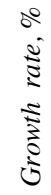 & $\frac{\pi}{2}$ & 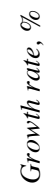 & $\frac{\pi}{\pi}$ & 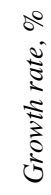 & $\frac{\tilde{s}}{\pi}$ & 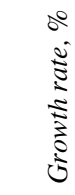 \\
\hline 1 & $\begin{array}{l}\text { The volume of shipped goods of own } \\
\text { production, works and services } \\
\text { performed on their own in the Russian } \\
\text { Federation, mln. rubles }\end{array}$ & 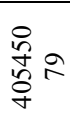 & 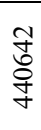 & $\begin{array}{l}\infty \\
\infty \\
\infty \\
\infty\end{array}$ & $\begin{array}{l}\stackrel{0}{6} \\
\stackrel{\sim}{n}\end{array}$ & 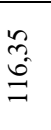 & $\frac{n}{2} 3$ & $\frac{2}{2}$ & $\begin{array}{l}\overline{0} \\
i n \\
\infty \\
i n\end{array}$ & ๙ֶ) \\
\hline 2 & $\begin{array}{l}\text { Investments in fixed assets in the } \\
\text { Russian Federation, billion rubles }\end{array}$ & 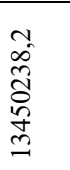 & 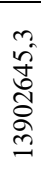 & 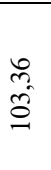 & $\underset{\substack{\infty \\
\infty}}{\substack{\infty\\
}}$ & ڤ̆ & \begin{tabular}{l}
$\hat{\sigma}$ \\
$\dot{0}$ \\
$\infty$ \\
$\infty$ \\
\multirow{J}{+}{} \\
J
\end{tabular} & $\frac{n}{\varrho}$ & 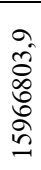 & \begin{tabular}{l}
$\stackrel{0}{1}$ \\
\multirow{\infty}{\infty}{} \\
$\stackrel{0}{-}$
\end{tabular} \\
\hline
\end{tabular}


Table 2. Continued

\begin{tabular}{|c|c|c|c|c|c|c|c|c|c|c|}
\hline 3 & $\begin{array}{l}\text { Dynamics of accounts receivable of } \\
\text { organizations (excluding small } \\
\text { businesses) in the Russian Federation, } \\
\text { billion rubles, total, including: }\end{array}$ & 芯 & $\underset{\frac{v}{0}}{\frac{\pi}{m}}$ & $\begin{array}{l}8 \\
\infty \\
=\end{array}$ & $\stackrel{\substack{n \\
n}}{m}$ & $\begin{array}{l}n \\
\tilde{n}\end{array}$ & 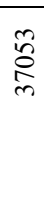 & 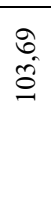 & 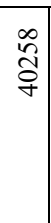 & $\begin{array}{l}0 \\
0 \\
\stackrel{0}{0}\end{array}$ \\
\hline $\begin{array}{l}3 . \\
1\end{array}$ & $\begin{array}{l}\text { overdue accounts receivable, billion } \\
\text { rubles }\end{array}$ & 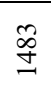 & $\stackrel{\circ}{\stackrel{\sim}{\sim}}$ & 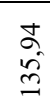 & 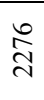 & 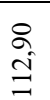 & $\bar{\Xi}$ & $\begin{array}{l}0 \\
+ \\
\infty \\
\infty\end{array}$ & సે & $\hat{\kappa}$ \\
\hline 4 & $\begin{array}{l}\text { Dynamics of accounts payable of } \\
\text { organizations (excluding small } \\
\text { businesses) in the Russian Federation, } \\
\text { billion rubles, total, including: }\end{array}$ & 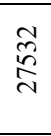 & $\underset{\substack{ \pm m}}{\stackrel{m}{I}}$ & $\begin{array}{l}q \\
\stackrel{\Xi}{二}\end{array}$ & $\underset{\substack{2 \\
\infty}}{\stackrel{n}{\infty}}$ & $\stackrel{\substack{n \\
ٍ}}{=}$ & 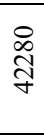 & $\begin{array}{l}\tilde{S} \\
\infty \\
0\end{array}$ & $\begin{array}{c}\bar{\infty} \\
\stackrel{+}{+} \\
\end{array}$ & $\overline{\tilde{n}}$ \\
\hline $\begin{array}{l}4 . \\
1\end{array}$ & $\begin{array}{l}\text { overdue accounts payable, billion } \\
\text { rubles }\end{array}$ & 尽 & $\begin{array}{l}\bar{\infty} \\
\stackrel{\infty}{\sim}\end{array}$ & $\stackrel{\circ}{\stackrel{\Xi}{\Xi}}$ & $\underset{\text { ন }}{\text { I }}$ & $\stackrel{m}{\stackrel{2}{a}}$ & $\begin{array}{l}\text { D } \\
\text { ర్d }\end{array}$ & $\stackrel{n}{2}$ & $\begin{array}{l}0 \\
\stackrel{0}{0} \\
\text { in }\end{array}$ & $\begin{array}{l}\underset{c}{g} \\
\infty\end{array}$ \\
\hline 5 & $\begin{array}{l}\text { Dynamics of the financial result of } \\
\text { organizations (excluding small } \\
\text { businesses) in the Russian Federation, } \\
\text { billion rubles }\end{array}$ & $\begin{array}{l}+ \\
\text { 心ٌ } \\
0\end{array}$ & $\underset{f}{f}$ & $\frac{7}{8}$ & 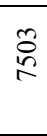 & 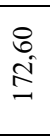 & 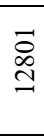 & $\stackrel{5}{\stackrel{0}{\Omega}}$ & હิి & $\begin{array}{l}\text { S. } \\
\infty \\
\infty\end{array}$ \\
\hline 6 & $\begin{array}{l}\text { Dynamics of return on assets of } \\
\text { organizations (excluding small } \\
\text { businesses) in the Russian } \\
\text { Federation, } \%\end{array}$ & $\stackrel{n}{*}$ & $\tilde{i}$ & $\begin{array}{l}n \\
n \\
n\end{array}$ & $\hat{m}$ & $\begin{array}{c}8 \\
\substack{0 \\
+}\end{array}$ & जे & ڤి & ?n & $\begin{array}{l}\infty \\
\infty \\
\infty\end{array}$ \\
\hline 7 & $\begin{array}{l}\text { Dynamics of profitability of sold } \\
\text { goods, products, works, services of } \\
\text { organizations (excluding small } \\
\text { businesses) in the Russian } \\
\text { Federation, } \%\end{array}$ & $r$ & $\stackrel{?}{2}$ & ते & $\vec{\infty}$ & $\begin{array}{l}\stackrel{2}{0} \\
ٍ\end{array}$ & $\stackrel{\circ}{\sim}$ & $\hat{\infty}$ & 2 & $\begin{array}{l}\infty \\
\stackrel{\infty}{0} \\
\alpha^{\infty}\end{array}$ \\
\hline 8 & $\begin{array}{l}\text { Current liquidity ratio (excluding small } \\
\text { businesses) in the Russian } \\
\text { Federation, } \%\end{array}$ & 今ે & $\vec{\Xi}$ & $\begin{array}{l}n \\
8 \\
8\end{array}$ & $\begin{array}{l}0 \\
\text { İ } \\
\text { In }\end{array}$ & $\begin{array}{l}\dot{H} \\
\stackrel{0}{\Xi}\end{array}$ & & $\begin{array}{l}n \\
n \\
\infty\end{array}$ & $\begin{array}{c}\infty \\
i \\
\end{array}$ & $\begin{array}{l}\hat{n} \\
\hat{\tilde{I}}\end{array}$ \\
\hline 9 & $\begin{array}{l}\text { Coefficient of provision with own } \\
\text { circulating assets (excluding small } \\
\text { businesses) in the Russian } \\
\text { Federation,\% }\end{array}$ & $\hat{\vec{\theta}}$ & $\stackrel{\overbrace{}}{7}$ & $\begin{array}{l}\infty \\
0 \\
0\end{array}$ & $\begin{array}{l}0 \\
\text { f } \\
\text { fy }\end{array}$ & $\begin{array}{l}8 \\
8 \\
8\end{array}$ & $\underset{\tilde{f}}{\tilde{f}}$ & $\begin{array}{l}\mathbb{Z} \\
\stackrel{8}{8}\end{array}$ & $\vec{a}$ & $\begin{array}{l}0 \\
\text { ñ } \\
\text { ñ }\end{array}$ \\
\hline $\begin{array}{l}1 \\
0\end{array}$ & $\begin{array}{l}\text { Autonomy coefficient (excluding small } \\
\text { businesses) in the Russian } \\
\text { Federation,\% }\end{array}$ & $\begin{array}{c}m \\
f\end{array}$ & $\vec{g}$ & $\begin{array}{l}\tilde{n} \\
\infty \\
\infty\end{array}$ & के & $\begin{array}{l}n \\
2 \\
\alpha\end{array}$ & $\begin{array}{l}n \\
\text { f }\end{array}$ & $\begin{array}{l}\tilde{n} \\
\text { ठ̊ } \\
0\end{array}$ & $\begin{array}{l}\infty \\
\stackrel{\sigma}{q}\end{array}$ & $\stackrel{\infty}{\stackrel{\infty}{\Xi}}$ \\
\hline
\end{tabular}

Table 3. Financial indicators of the activities of commercial banks in the Russian Federation in the context of balance sheet portfolios in 2013-2017

\begin{tabular}{|c|c|c|c|c|c|c|c|c|c|c|c|c|c|c|c|}
\hline \multirow[b]{2}{*}{$\mathrm{N}$} & \multirow[b]{2}{*}{$\begin{array}{c}\text { Indicator } \\
\text { name }\end{array}$} & \multicolumn{2}{|c|}{2013} & \multicolumn{3}{|c|}{2014} & \multicolumn{3}{|c|}{2015} & \multicolumn{3}{|c|}{2016} & \multicolumn{3}{|c|}{2017} \\
\hline & & $\begin{array}{l}\text { चे } \\
\text { चี } \\
\text { ص }\end{array}$ & 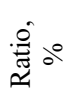 & 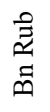 & $\stackrel{\stackrel{\overbrace{}}{\overparen{E}}}{\simeq} \circ^{\circ}$ & 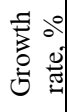 & 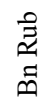 & $\stackrel{0}{\stackrel{0}{\overparen{c}}} \circ$ & 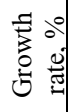 & 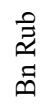 & 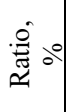 & 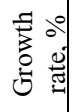 & 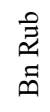 & $\stackrel{\mathscr{B}}{\approx} \circ$ & 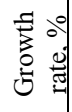 \\
\hline 1 & $\begin{array}{l}\text { Money } \\
\text { portfolio }\end{array}$ & केे & $\stackrel{\hat{\infty}}{m}$ & $\frac{n}{\infty}$ & $\stackrel{\leftrightarrow}{\circ}$ & \begin{tabular}{l} 
? \\
\multirow{f}{0}{}
\end{tabular} & $\begin{array}{l}0 \\
\infty \\
i n \\
i\end{array}$ & ले & $\frac{n}{\infty}$ & 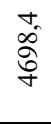 & $\vec{\sigma}$ & 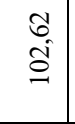 & 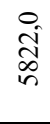 & $\stackrel{尺}{\stackrel{f}{f}}$ & $\overline{\widehat{\jmath}}$ \\
\hline 2 & $\begin{array}{l}\text { Loan } \\
\text { portfolio }\end{array}$ & $\begin{array}{l}0 \\
0 \\
0 \\
0 \\
0\end{array}$ & $\begin{array}{l}\text { oे } \\
\text { \& }\end{array}$ & $\begin{array}{l}\stackrel{m}{=} \\
\overrightarrow{\widehat{\sigma}}\end{array}$ & $\begin{array}{l}\infty \\
\dot{\infty} \\
\infty \\
\infty\end{array}$ & $\begin{array}{l}\text { जे } \\
\text { ปิ }\end{array}$ & 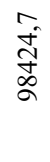 & $\frac{n}{\infty}$ & $\begin{array}{l}m \\
\stackrel{n}{0} \\
=\end{array}$ & 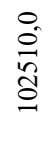 & $\begin{array}{l}0 \\
n_{n} \\
\infty\end{array}$ & $\begin{array}{l}n \\
\stackrel{0}{0}\end{array}$ & $\begin{array}{l}\infty \\
\text { ڤ్ } \\
\text { సิ }\end{array}$ & \begin{tabular}{l}
$\tilde{2}$ \\
\multirow{\infty}{\infty}{}
\end{tabular} & $\begin{array}{l}\bar{F} \\
\dot{8}\end{array}$ \\
\hline
\end{tabular}


Table 3. Continued

\begin{tabular}{|c|c|c|c|c|c|c|c|c|c|c|c|c|c|c|c|}
\hline 3 & $\begin{array}{l}\text { Investme } \\
\text { nt } \\
\text { portfolio }\end{array}$ & के & $\underset{\infty}{\infty}$ & $\underset{\infty}{\stackrel{+}{+}}$ & $\underset{\infty}{\stackrel{9}{\infty}}$ & $\begin{array}{l}\stackrel{\sim}{2} \\
\stackrel{ \pm}{I}\end{array}$ & $\begin{array}{l}\hat{\circ} \\
\text { ठे }\end{array}$ & $\vec{n}$ & $\begin{array}{l}\text { İ } \\
\text { ה̃ }\end{array}$ & $\begin{array}{l}\hat{6} \\
\stackrel{0}{=} \\
=\end{array}$ & $\begin{array}{l}n \\
0\end{array}$ & $\begin{array}{l}\text { Fे } \\
\infty \\
\stackrel{0}{0}\end{array}$ & $\begin{array}{l}\hat{\infty} \\
\infty \\
\infty \\
=\end{array}$ & $\underset{\sigma}{\stackrel{ \pm}{a}}$ & $\begin{array}{l}\tilde{n} \\
\tilde{\delta} \\
\tilde{0}\end{array}$ \\
\hline 4 & $\begin{array}{l}\text { Fixed } \\
\text { capital } \\
\text { portfolio }\end{array}$ & aे & $\stackrel{\text { ? }}{\rightarrow}$ & $\vec{n}$ & $\tilde{\delta}$ & 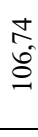 & 官 & $\begin{array}{l}\check{\sigma} \\
\hat{\sigma}\end{array}$ & \begin{tabular}{l}
$n$ \\
\multirow{2}{n}{} \\
0
\end{tabular} & 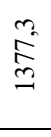 & $\stackrel{\approx}{=}$ & Iิ & $\hat{\vec{m}}$ & 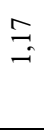 & ले \\
\hline \multicolumn{2}{|c|}{$\begin{array}{l}\text { Total } \\
\text { Qualified } \\
\text { Assets }\end{array}$} & ถุ้ & 8 & $\frac{\overline{\tilde{N}}}{\frac{\pi}{2}}$ & 8 & $\frac{1}{2}$ & 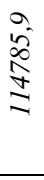 & $\begin{array}{l}8 \\
8\end{array}$ & 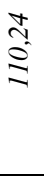 & 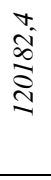 & 8 & $\begin{array}{l}\frac{8}{8} \\
\text { id }\end{array}$ & $\begin{array}{l}\text { aे } \\
\text { ปิ }\end{array}$ & $\begin{array}{l}8 \\
8\end{array}$ & $\frac{n}{2}$ \\
\hline 1 & $\begin{array}{l}\text { Loan } \\
\text { portfolio }\end{array}$ & f & ${ }_{0}^{8}$ & $\begin{array}{l}0 \\
\infty \\
\infty \\
\infty \\
i n\end{array}$ & कुे & $\begin{array}{l}\infty \\
n \\
n \\
n\end{array}$ & ণ্ণু & $\vec{i}$ & 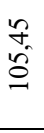 & $\begin{array}{l}\infty \\
\frac{\dot{J}}{\infty}\end{array}$ & $\stackrel{0}{\stackrel{2}{n}}$ & $\frac{\hat{\sigma}}{\sigma}$ & $\underset{\infty}{\infty}$ & ఫુ & 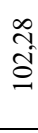 \\
\hline 2 & $\begin{array}{l}\text { Deposit } \\
\text { portfolio }\end{array}$ & वे. & $\begin{array}{l}: \\
\stackrel{0}{\infty}\end{array}$ & $\begin{array}{l}m \\
\stackrel{\infty}{\infty} \\
\infty \\
\infty\end{array}$ & $\begin{array}{l}\forall \\
\vdots \\
\infty\end{array}$ & 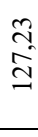 & 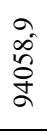 & fo & $\begin{array}{l}\tilde{\partial} \\
\stackrel{\partial}{=}\end{array}$ & $\begin{array}{l}n \\
8 \\
8 \\
8\end{array}$ & $\begin{array}{l}\text { fo } \\
\text { f } \\
\infty\end{array}$ & $\begin{array}{l}\bar{\infty} \\
0 \\
0 \\
0\end{array}$ & $\begin{array}{l}\stackrel{8}{0}^{\circ} \\
\frac{\sigma}{\sigma}\end{array}$ & $\begin{array}{l}\stackrel{0}{0} \\
\infty \\
\infty\end{array}$ & $\begin{array}{l}n \\
0 \\
0\end{array}$ \\
\hline 3 & $\begin{array}{l}\text { Equity } \\
\text { portfolio }\end{array}$ & จे & 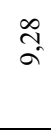 & 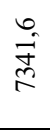 & $\hat{a}$ & $\begin{array}{l}\tilde{c} \\
\infty \\
0 \\
0\end{array}$ & $\hat{n}_{\infty}$ & 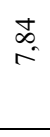 & 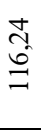 & $\underset{\hat{\sigma}}{\dot{\sigma}}$ & $\underset{\infty}{\vec{\sigma}}$ & 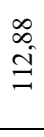 & $\begin{array}{l}\text { ڤ్ } \\
\stackrel{0}{\sigma} \\
0\end{array}$ & $\vec{n}$ & $\begin{array}{l}5 \\
\stackrel{0}{0}\end{array}$ \\
\hline & $\begin{array}{l}\text { tal } \\
\text { alified } \\
\text { bilities }\end{array}$ & 气ै? & 8 & $\frac{n}{\underset{\pi}{\pi}}$ & $\stackrel{8}{8}$ & 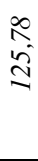 & $\begin{array}{l}\tilde{1} \\
\tilde{\delta} \\
\infty \\
\approx\end{array}$ & $\stackrel{8}{8}$ & $\begin{array}{l}\overline{7} \\
0^{\infty} \\
=\end{array}$ & 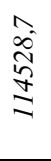 & $\stackrel{8}{8}$ & $\begin{array}{l}i \\
i \\
i \\
2\end{array}$ & 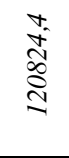 & $\stackrel{8}{8}$ & $\begin{array}{l}2 \\
2 \\
2 \\
2\end{array}$ \\
\hline
\end{tabular}

The results of the study of these portfolios of banking products indicate the overall positive dynamics of the development of the Russian banking system.

1. The monetary portfolio of commercial banks, consisting of highly liquid assets, such as cash, accounts with the Bank of Russia, correspondent accounts with other banks, increased over the analyzed period by $87.99 \%$. This indicates an increase in the level of banks' responsibility for the fulfillment of their current obligations and the obligations of clients.

2. The loan portfolio is represented by loans and equivalent banking products provided to organizations in various sectors of the economy and individuals; it is the main profitable banking product that generates bank profits, accounting for more than $80 \%$ of qualified assets. From 2013 to 2017 , it grew by $49.45 \%$.

3. Investment portfolio of banks, containing government and corporate securities, investments in which are profitable banking products. During the analyzed period, there was a tendency for the investment activity of credit institutions to grow by $69.07 \%$.

4. The portfolio of fixed assets creates a material basis for the functioning of banks in the form of buildings, equipment, vehicle fleet, as well as intangible assets (licenses, software products, etc.). The analysis shows its growth by $43.49 \%$.

5. The loan portfolio as a means of ensuring current banking liquidity is traditionally the most unstable type of banking resources, subject to the influence of external and internal factors - its growth in five years became the maximum - $88.71 \%$ - among other banking portfolios.

6. The deposit portfolio of commercial banks is the main source of banking resources, it includes the funds of clients - legal entities and individuals, placed for a certain 
period or on demand, including funds from other banks, as well as investments in securities that are debt obligations of the bank (bank bills, certificates, bonds). This place of deposits in the resource base of Russian credit institutions determines their steady growth in the analyzed period, which amounted to $64.77 \%$.

7. The portfolio of banks' own funds (capital) as the financial basis of their activities grew 1.5 times.

The analysis of the balance sheet portfolios of operating Russian banks allows us to state the following. With the overall positive dynamics of the development of banking activities more than 1.5 times, there is an outstripping growth in the money and loan portfolios, which is invariably associated with the emergence of current liquidity problems and the need to ensure timely fulfillment of urgent obligations. Along with this, there is a significant increase in deposits of legal entities, deposits of individuals, as well as balances of funds of organizations on settlement accounts.

Analysis of financial management objects of banks in the Russian Federation in the context of balance sheet portfolios for 2013-2017 indicates the achieved level of development of the banking business in the Russian Federation.

The presented data on the practical functioning of the financial management system of organizations included in the empirical base of this study indicate an acceptable level of its effectiveness and the feasibility of widespread use of the proposed methodology.

This research is devoted to the issues of financial management of organizations in various sectors of the economy. A scientific concept related to the formation of a financial management system for organizations (enterprises) is formulated and described. A literary review of the research topic was carried out, highlighting the most controversial aspects. On the example of the Russian economy, the objects of financial management of organizations and banks are analyzed according to the selected financial indicators. Conclusions are made about the state of financial management in organizations and banks of the Russian Federation, prospects for the application of the developed theory of financial management of organizations (enterprises) in various spheres of the economy in practice in various countries are outlined.

The obtained results of the analysis of financial indicators of the activities of organizations and banks of the Russian Federation by objects of financial management in 2013-2017 indicate the presence of certain problems with the achievement of target parameters, which was a consequence of the impact of both external factors (crisis phenomena in the economy) and internal factors (low quality of financial decision-making). A qualitative coincidence of the author's results with the results presented in other sources on the problem under study has been established.

\section{Conclusions}

The problem of organizing financial management of economic entities in various spheres of the economy studied in the article is reduced to the formation of an effective financial management system that harmoniously combines all the necessary components. The result of the application of the obtained theoretical and methodological knowledge in practice is improvement of the quality of financial decision-making at the level of individual business entities and, as a consequence, the achievement of the goals set by the management entities.

The international approaches of scientists studying the problems of finance of organizations (enterprises) and financial management have been studied.

The organizational and economic nature of the elements of the financial management system of organizations (enterprises) and commercial banks have been determined, and the patterns of the formation of these systems in organizations of different spheres of the economy have been identified. 
The analysis of the financial activities of organizations in different spheres of the economy has been carried out according to their inherent objects of financial management, on the basis of which the efficiency of the functioning of the financial management system of the studied organizations has been determined.

\section{References}

1. A. Abdul-Rahman, Pacific-Basin Finance Journal (2017)

2. F. Allen, Journal of Financial Intermediation (2018)

3. M.V. Charayeva, M.H. Diratsuyan, Current problems of humanitarian and natural sciences, 12-3, 155 (2015)

4. M.I. Cherutova, O.V. Cherutova, Works of BRGU, Series: Economy and management, 132 (2015)

5. Christophe Schinckus, International Review of Financial Analysis, 40, 103 (2015)

6. Deniz Anginer, Asli Demirgüc,-Kunt, Davide S. Mare, Journal of Financial Stability, 37, 97 (2018)

7. Douglas Cumming, Alexander Peter Groh, Journal of Corporate Finance, 50, 538 (2018)

8. Erbao Cao, Lingxia Du, Junhu Ruan, International Journal of Production Economics (2018)

9. Fabian Valencia, Journal of Banking \& Finance, 69, S1 (2016)

10. N.V. Feshchenko, Scientific messenger of The Baikal state university of economy and the right, 2(26), 59 (2015)

11. M.K. Fisenko, Messenger of The Polotsk state university Series D, 6, 47 (2014)

12. L. Gan, North American Journal of Economics and Finance (2018)

13. General System theory: Foundations, Development, Applications, 289 (1968)

14. M.A. Gorodilov, K.Yu. Kotova, Messenger of SGEU, 1(159), 60 (2018)

15. V.F. Grankin, I.N. Marchenkova, A.A. Udovikova, Messenger of The Kursk state agricultural academy, 4, 66 (2017)

16. Jordi Paniagua, Rafael Rivelles, Juan Sapena, Journal of Business Research, 89, 229(2018)

17. S.I. Krylov, Economic analysis: theory and practice, 18(417), 2 (2015)

18. A.A. Kurilova, N.V. Kolacheva, Karelian scientific magazine, 1(18), 67 (2017)

19. Mark J. Flannerya, Kristine Watson Hankins, Journal of Corporate Finance, 19, 1 (2013)

20. Michaël Dewallya, Yingying Shao, Journal of Banking \& Finance, 39, 223 (2014)

21. Miguel Tavares-Gärtner, Paulo J. Pereira, Elísio Brandão, European Journal of Operational Research, 270, 1182 (2018)

22. Ming-Lang Tseng, Kuo-Jui $\mathrm{Wu}$, Jiayao $\mathrm{Hu}$, Chin-Hsin Wang, International Journal of Production Economics, 205, 30 (2018)

23. A.Yu. Kazak, O.B. Veretennikova, M.S. Maramygin, K.V. Rostovtsev, Monetary economy of enterprises: the textbook for higher education institutions, 464 (2006)

24. N.N. Muravyeva, Problems of modern economy, 33, 133 (2016) 
25. N. Yan et al., Financing the capital-constrained supply chain with loss aversion: supplier finance vs. Supplier investment (2018)

26. Norfaizah Othman, Mariani Abdul-Majid, Aisyah Pacific-Basin Finance Journal, 46, 1 (2017)

27. A.V. Penyugalova, A.A. Zimina, Financial analytics: problems and decisions, 25, 11 (2015)

28. Peter Benczur, Stelios Karagiannis, Virmantas Kvedaras, Journal of Macroeconomics (2018)

29. N.S. Piontkevich, Financial management of economic entity and financial risks, 252 (2015)

30. Rebel A. Cole, Tatyana Sokolyk, Journal of Corporate Finance, 50, 609 (2018)

31. T.P. Satsuk, Innovative development of economy, 3(33), 295 (2016)

32. E.R. Semyonova, Messenger of modern science, 2, 99 (2016)

33. M.M. Shapsigov, L.A. Shakova, M.A. Maremshaova, Management of economic systems: online scientific magazine, 4(86), 6 (2016)

34. E.B. Sharova, Sustainable development of science and education, 1, 62 (2016)

35. E.G. Shatkovskaya, Formation and realization of financial policy of credit institution in conditions of concord regulation, 396 (2015)

36. A.P. Suvorova, P.A. Korotkova, Scientific online magazine "Matrix of scientific knowledge", 11, 69 (2017)

37. A.A. Tarasov, Administrative sciences, 7.4, 54 (2017)

38. A.V. Vorotyntseva, D.V. Solomakhina, Innovative economy: prospects of development and improvement, 4(22), 40 (2017)

39. Xinhan $\mathrm{Xu}, \mathrm{Xiangfeng} \mathrm{Chen}, \mathrm{Fu}$ Jia, Steve Brown, Yu Gong, Yifan Xu, International Journal of Production Economics, 204, 160 (2018)

40. Xun Zhang, Zongyue He, Jiali Zhu, Jing Li, North American Journal of Economics and Finance, 44, 129 (2018)

41. O.A. Yevstigneyeva, Vector of science TGU. Series: Economy and management, 3(18), 34 (2014)

42. Zhan J, Li S, Chen X, Journal of Cleaner Production (2018)

43. V.N. Zhukov, Manager, 1/59, 44 (2016) 